\title{
RELATIONSHIP BETWEEN MORPHOLOGICAL CHARACTERISTICS AND PHYSICAL ABILITIES IN VOLLEYBALL PLAYERS
}

\author{
Goran Glamočić', Branislav Strajnić1, Branko Đukić1, Vladimir Ivanek² \\ ${ }^{1}$ Provincial Institute for Sports and Sport Medicine, Novi Sad \\ ${ }^{2}$ Faculty of Humanities and Social Sciences, University of Mostar
}

Original scientific paper

\begin{abstract}
This research aims to determine the relationship between morphological characteristics and abilities in volleyball players. It was conducted on the territory of Vojvodina autonomous province on a sample of 27 male volleyball players with an average age of $17.48 \pm 0.50$ years and an average sports experience of $6.33 \pm 2.83$ years. A test battery consisting of five variables for measuring morphological characteristics and twelve tests of abilities was applied: flexibility, speed, agility, endurance, static and explosive power. The normality of the data distribution was controlled by the Shapiro-Wilk test, and the connection between morphological characteristics and abilities was calculated by the Spearman ro correlation coefficient. The limit value for testing the normality of distribution of $p>$ 0.05 was not met by: body mass index $(p=0.01)$, straddle in supine position $(p=0.03)$, single leg counter movement jump with the left leg $(p=0.01)$ and Yo-Yo Intermittent endurance test level $2(p=0.02)$. The connection of morphological characteristics with explosive power tests is especially noticeable, the most significant is the range of arms span with continuous jump with bent legs (ro $=0.75$ ), single leg counter movement jump with the right leg (ro $=0.74$ ) and Counter movement jump (ro $=0.63$ ). The main finding in this study is that morphological characteristics are mostly negatively correlated with the explosive power of volleyball players. It is known that these characteristics and abilities have a significant share in the model of the ideal volleyball player and therefore their negative connections, the approach to the selection of volleyball and volleyball training must be based on scientific knowledge. Key words: measurement, testing, diagnostics, test batteries, volleyball
\end{abstract}

\section{INTRODUCTION}

Volleyball is one of the most popular, most active, but at the same time one of the fastest sports games in the world. Volleyball team has 12 players with a large number of positions in the game. Each of these positions plays a role in a volleyball game. Volleyball is a sport of medium and submaximal intensity characterized by polystructural movements. There are two basic phases in volleyball: the online game and the field game phase. Due to these phases of the game, and due to the overall actions in the game which are divided into active and passive phase, and interruptions, the functional mechanism that prevails during the volleyball game is mixed, in other words aerobic-anaerobic (Janković and Marelić 1995). Modern volleyball game requires from all players a high level of general physical abilities, as well as specific characteristics of the volleyball game and for certain playing positions (Martinović et al. 2011). For the successful implementation of selection in volleyball, the key role is played by the equation of specification, which includes anthropometric characteristics, functional, physical, conative and cognitive abilities as well as the level of technical and tactical knowledge. Although this equation is never clearly defined, most authors believe that in volleyball they are: body height, arm length, finger length, pelvic circumference, ball feel, speed-strong ability, coordination of movements, speed of reaction time, vertical jumping, speed of sensometric reaction, steadfastness of attention, speed of information processing and operational thinking. Successful volleyball is characterized by pronounced body height, jumping abilities, as well as technical and tactical abilities (Gabbett et al., 2007; Malousaris et al., 2008; Rickberg and Raudsepp, 2011; Sheppard et al., 2009). Skeleton longitudinal dimensionality, explosive power and coordination (primarily agility) have the greatest influence on success in volleyball. Subcutaneous adipose tissue has a negative impact on success in the game (Marelić et al. 2007). In sports, it is very important to know the connection between different characteristics and abilities of anthropological status (Krneta, 2019). In the following study, the relationship between morphological characteristics and physical abilities of forty-two professional volleyball players of the Spanish Super League with an average age of $27.2 \pm 5.4$ years was presented.

Significant positive correlations ( $p<0.05$ ) were found between tests to assess the explosive power of the lower extremities (maximum reach in the block and smash) and skin folds of the upper leg and lower leg. Further, both jumps (VJ and $\mathrm{SJ}$ ) showed negative correlations with age and absolute mechanical strength of the tested 
jumps (Mielgo-Ayuso et al. 2014). A study conducted in Greece in which sixty-four young volleyball players with an average age of $14.4 \pm$ 0.5 participated concluded that there were moderate positive correlations between body height and maximum retrieval reach in the trash and small and moderate negative correlations between body mass index and leather fold on one side and maximum reach in the spike and block on the other (Tsoukos et al. 2019). In order to examine the influence of anthropometric characteristics on the manifestation of explosive power (jumping), an experimental research was organized on a sample of 40 volleyball players aged 13 years. It was concluded that the applied system of anthropometric characteristics, as a predictor, has a significant impact on the manifestation of explosive power in volleyball players aged 13 (Stojanović et al. 2006).

\section{METHODS}

This research was conducted in order to determine the connection between morphological characteristics and physical abilities in a selected group of respondents from the existing and available data generated in the Provincial Institute for Sports and Sports Medicine Novi Sad during the procedure of diagnosing athletes' training. 27 male volleyball players with an average age of $17.48 \pm 0.50$ years and an average sports experience of 6.33 \pm 2.83 years were selected. All tests and measurements were performed in the field by employees of the Provincial Institute for Sports and Sports Medicine on the territory of Vojvodina autonomous region during 2019 and 2020. The applied battery of measurements and testing is standard in the Institute in cases when field tests of volleyball training diagnostics are performed. Measurements of morphological characteristics included: body height (VT), body weight (MT), body mass index (BMI), arm span (RR) and retrieval height (DV). Measurement of body height, arm span and retrieval height was performed with an anthropometer according to Martin with an accuracy of $0.1 \mathrm{~cm}$. Body mass was measured by bioelectrical impedance (BIA) with an accuracy of $0.1 \mathrm{~kg}$, in addition to body weight, a body mass index $(\mathrm{kg} / \mathrm{m} 2)$ was obtained. The battery of physical tests consisted of: sit and reach (SAR) and straddle in supine position (SSP) for flexibility testing, visual reaction time (VRT) for speed testing, shuttle run $10 \times 5$ meters (SHR) for agility testing, Hand grip (HGR) for static strength testing, squat jump (SJ), counter movement jump (CMJ), single leg counter movement jump with the right leg (CMJR), single leg counter movement jump with the left leg (CMJL), maximal counter movement jump (CMJmax) and continuous jump with bent legs (CJB) for explosive power testing and Yo-Yo Intermittent endurance test level 2 (YYIE2) for endurance testing. All protocols for physical tests followed the instructions from the book Testing and Assessing Athletes' physical abilities at the Provincial Institute for Sports and Sports Medicine (Glamočić and Ivanov, 2019). Values and results of measurements and testing are presented as arithmetic mean (M) and standard deviation (SD), the normality of the distribution is controlled by the Shapiro-Wilk test. The correlation between morphological characteristics and abilities was calculated using the Spearman's rank correlation coefficient. The analysis of the obtained data was done with the help of the open source statistical data processing program GNU PSPP 1.4.1-g79ad47.

\section{RESULTS}

Table 1 shows the results of measuring morphological characteristics and testing physical abilities. The average results of morphological characteristics of volleyball players obtained in this study when compared with the results of other studies for other sports, but the same sex and age indicate above average values for body height (193.7 \pm 7.49, arm span $(197.9 \pm 8,1)$ and body weight $(82.3 \pm$ 8.3) and average values for body mass index $(21.9 \pm 1.8)$. Based on the values of standard deviations, it is noticed that the distributions are the most stretched at the retrieval height, straddle in supine position and yo-yo interval endurance test level 2. Volleyball players were the most homogeneous in terms of body mass index, visual reaction time, shuttle run $10 \times 5$ and hand grip absolutely.

By testing the distribution normality of the obtained results with the Shapiro-Wilk test shown in Table 1, it can be concluded that most of the values exceed the limit value $p>0.05$. If we discard p-values and a little higher than the limit value $p>0.05$, the chance of error would be high ( $5 \%)$. By controlling the $p$-value, we discard from further analysis the following tests that did not meet this condition: body mass index $(p=0.01)$, Straddle in supine position ( $p=$ $0.03)$, Squat jump with preparation on the left leg $(p=0,01)$ and a yo-yo interval endurance test of level $2(p=0.02)$. In other words, the difference between the sample of these results and the normal distribution is large enough to be statistically significant, not in the range of accepted Shapiro-Wilk test values of $95 \%$. 
Table 1. Measurements results, testing and distribution normality test

\begin{tabular}{llll}
\hline & & \multicolumn{2}{l}{ Shapiro-Wilk test } \\
& $\mathrm{M} \pm \mathrm{SD}(\mathrm{n}=27)$ & $\mathrm{W}$ & $\mathrm{p}$ \\
\cline { 2 - 4 } Body height $(\mathrm{cm})$ & $193.7 \pm 7.4$ & 0.93 & 0.07 \\
Arm span $(\mathrm{cm})$ & $197.9 \pm 8.1$ & 0.95 & 0.22 \\
Retrieval height $(\mathrm{cm})$ & $253.4 \pm 11.8$ & 0.95 & 0.3 \\
Body weight $(\mathrm{kg})$ & $82.3 \pm 8.3$ & 0.96 & 0.29 \\
Body mass index $(\mathrm{kg} / \mathrm{m} 2)$ & $21.9 \pm 1.8$ & 0.89 & 0.01 \\
Sit and reach $(\mathrm{cm})$ & $27.5 \pm 6.6$ & 0.93 & 0.08 \\
Straddle in supine position (0) & $97.2 \pm 16.7$ & 0.92 & 0.03 \\
Visual reaction time (s) & $0.30 \pm 0.03$ & 0.96 & 0.4 \\
Shuttle run 10 x 5 meters (s) & $17.45 \pm .62$ & 0.95 & 0.26 \\
Hand grip (kg) & $52.4 \pm 5.8$ & 0.94 & 0.17 \\
Squat jump (cm) & $36.0 \pm 7.8$ & 0.97 & 0.74 \\
Counter movement jump (cm) & $39.1 \pm 6.9$ & 0.96 & 0.46 \\
Single leg counter movement jump with the right leg (cm) & $17.8 \pm 4.7$ & 0.95 & 0.2 \\
Single leg counter movement jump with the left leg (cm) & $18.4 \pm 4.3$ & 0.89 & 0.01 \\
Maximal counter movement jump (cm) & $47.9 \pm 8.3$ & 0.93 & 0.1 \\
Continuous jump with bent legs (cm) & $33.2 \pm 6.9$ & 0.95 & 0.3 \\
Yo-Yo Intermittent endurance test level 2 (m) & $760 \pm 338$ & 0.9 & 0.02 \\
\hline
\end{tabular}

Legend: w- Shapiro-Wilk test value, $\mathrm{p}$ - Shapiro-Wilk significance test

Table 2 shows the values of Spearman's ro correlation coefficient between the parameters of morphological characteristics and physical abilities. Authors who have studied the relationship strength between two variables give different guidelines for its interpretation. In this study, we opted for the interpretation according to which the correlation values between ro = $0.10-0.29$ represent a small correlation, between ro $=0.30-0.49$ medium and between ro $=0.50$ 1.00 large correlation (Cohen, 1988, pp. 79-81).

Table 2. Morphological and physical variables correlation (Spearman's rank correlation coefficient)

\begin{tabular}{ccccc}
\hline & & Arm & & \\
& Body height & span & Retrieval height Body mass \\
\hline Sit and reach & -0.06 & -0.26 & -0.21 & 0.1 \\
Visual reaction time & 0.01 & -0.09 & -0.21 & -0.09 \\
Shuttle run 10 x 5 meters & 0.29 & 0.49 & 0.34 & 0.71 \\
Hand grip & 0.13 & 0.07 & 0.13 & 0.17 \\
Squat jump & -0.31 & -0.4 & -0.31 & -0.19 \\
Counter movement jump & -0.47 & -0.63 & -0.50 & -0.44 \\
Single leg counter movement jump with the & -0.59 & -0.74 & -0.69 & -0.55 \\
right leg & & & & \\
Maximal counter movement jump & -0.35 & -0.42 & -0.43 & -0.44 \\
Continuous jump with bent legs & -0.61 & -0.75 & -0.69 & -0.51 \\
\hline
\end{tabular}

Table 2 clearly shows a significant number of large correlations. We see that the morphological characteristics of volleyball players are mostly related to explosive power. Strong correlation of arm span with Continuous jump with bent legs (ro $=0.75$ ), single leg counter movement jump with the right leg with (ro $=0.74$ ) and with Counter movement jump (ro $=0.63$ ) is especially noticeable. Then a large correlation between retrieval height, body height and body weight with the same tests. In all these correlation cases of morphological characteristics and test results of explosive power of volleyball players, there is a strong negative correlation. High values of morphological characteristics are followed by low results on explosive power tests. The morphological characteristics are least closely 
related to the tests of flexibility (SAR), velocity (VRT) and static strength (HGR), but in agility (SHR) a large linear relationship was observed with body mass. Since the Shuttle run test $10 \mathrm{x}$

\section{DISCUSSION}

For many authors, the connection between volleyball player's morphological characteristics and physical abilities has been the subject of research, especially in terms of selection, specialization, equation of specification and prediction of the results of skills and abilities. This is confirmed by Stam et al. (2003) when they say that most previous research in volleyball indicates that body height and body composition play a big role in playing performance. Most authors (Janković, \& Marelić, 1995; Kostić, 1995; Nejić, 2005; Nešić, 2006; cited in Trajković, 2015, p. 11). considers strength, speed, coordination and flexibility important, but singles out explosive power as the most important ability.

The main finding in this research is that morphological characteristics mostly have a negative correlation with the explosive power of volleyball players, and further research could lead to the conclusion of what predictor influence they could have. Here, it is important to remember that these morphological
5 meters lower value represents a better result and this is a negative correlation, high values of body weight measurements are followed by low results on the agility test (SHR).

characteristics (apart from body weight) and physical ability of the explosive power in the equation of the specification of the ideal volleyball player play an extremely important role. This means that a top volleyball player must have markedly high values of measuring the skeleton longitudinal dimensions, but also markedly high results in explosive power. Obviously, based on this research, these two things are contradictory, but because of that, a serious approach to the selection of volleyball and volleyball training, based on scientific knowledge, comes to the fore during sports training. Marques, Roland, Vescovi, \& GonzálezBadillo (2008) in their research with the aim to determine how programmed training affects the improvement of especially explosive power, conclude that it is possible with good programming of plyometric training and strength exercises to increase explosive power. Nebojsa Trajkovic (2015), in his research, says that the applied "model of situational-fitness training program had significant effects on the development of explosive power, in volleyball players aged 15 to $18 "$.

\section{REFERENCES}

1. Cohen, J. (1988). Statistical Power Analysis for the Behavioral Sciences, New Jersey, Lawrence Erlbaum Associates. Inc. Publishers.

2. Gabbett, T., Georgieff, B. (2007). Physiological and Anthropometric Characteristics of Australian Junior National, State, and Novice Volleyball Players. J Strength Cond Res, 2007; 21(3): 902-908.

3. Gabbett, T. and Georgieff, B. (2006). Changes in skill and physical fitness following training in talentidentified volleyball players. J Strength Cond Res 20: 29-35, 2006.

4. Glamočić, G. and Ivanov, Đ. (2019). Testiranje i ocenjivanje motoričkih sposobnosti sportista u Pokrajinskom zavodu za sport i medicinu sporta. Novi Sad: Pokrajinski zavod za sport i medicinu sporta.

5. Janković, V., \& Marelić, N. (1995). Odbojka (Volleyball). Zagreb, HR: Fakultet fizičke kulture.

6. Krneta, Ž. (2019). Osnove istraživanja u sportu i fizičkom vaspitanju. Novi Sad: Fakultet sporta i fizičkog vaspitanja.

7. Malousaris, GG., Bergeles, NK., Barzouka, KG., Bayios, IA., Nassis, GP., Koskolou, MD. ( 2008). Somatotype, size and body composition of competitive female volleyball players. J Sci Med Sport; 11(3): 337-344.

8. Marelić, N., Đurković, T. \& Rešetar, T. (2007). Dijagnostika kondicijskih sposobnosti mlađih dobnih kategorija u odbojci. U: Peta godišnja međunarodna konferencija Kondicijska priprema sportaša (277-282). Zagreb: Kineziološki fakultet sveučilišta u Zagrebu i Zagrebački športski savez.

9. Marques, M. C., Roland, T., Vescovi, J. D., \& González-Badillo, J. J. (2008). Changes in Strength and Power Performance in Elite Senior Female Professional Volleyball Players During the In-Season: A Case Study. Journal of Strength and Conditioning Research, 22 (4), 1147-1155.

10. Martinović, J., Dopsaj, V., Kotur-Stevuljević, J., Dopsaj, M., Vujović, A., Stefanović, A., \& Nešić G. (2011). Oxidative stress biomarker monitoring in elite women volleyball athletes during a 6 -week training period. J Strength Cond Res, 25(5), 1360-1367. doi: 10.1519/JSC.0b013e3181d85a7f; PMid: 21157395.

11. Mielgo-Ayuso, J., Calleja-González, J., Clemente-Suárez, VJ., Zourdos, MC. (2014). Influence of anthropometric profile on physical performance in elite female volleyballers in relation to playing position. Nutr Hosp. 2014 Oct 6;31(2):849-57. doi: 10.3305/nh.2015.31.2.7658. PMID: 25617573.

12. Rikberg, A., Raudsepp, L. (2011). Multidimensional performance characteristics in talented male youth volleyball players. Pediatr Exerc Sci., 2011; 23(4): 537-548.

13. Sheppard, JM., Gabbett, TJ., Stanganelli, LCR. (2009). An analysis of playing positions in elite mens volleyball: considerations for competition demands and physiologic characteristics. J Strength Cond Res, 2009; 23(6): 1858-1866. 
14. Stamm, R., Veldre, G., Stamm, M., Thomson, K., Kaarma, H., Loko, J., Koskel, S. (2003). Dependence of young female volleyballers performance on their body build, physical abilities, and psycho-physiological properties. J Sports Med Phys Fitness, 2003; 43(3): 291-299.

15. Stojanović, T., Nikolić, M., \& Nešić, G. (2006). Uticaj antropometrijskih karakteristika na manifestaciju eksplozivne snage kod odbojkaša uzrasta 13 godina (The influence of anthropometric characteristics on explosive strength manifestation in volleyball players aged 13 years). Acta Medica Medianae, 45(2), 48-52.

16. Trajković, N. (2015). Uticaj situaciono-kondicionog treninga na eksplozivnu snagu i preciznost kod odbojkaša. Doktorska disertacija, Niš: Fakultet sporta i fizičkog vaspitanja, Univerzitet u Nišu.

17. Tsoukos, A., Drikos, S., Brown, L., Sotiropoulos, K., Veligekas, P., Bogdanis, G. (2019). Anthropometric and physical Performance Variables Are Decisive Factors for The Selection of Junior National Female Volleyball Players. Journal of Human Kinetics. 67. 163-173. 10.2478/hukin-2019-0012.

\section{Correspondence to:}

Goran Glamočić

Provincial Institute for Sports and Sport Medicine,

Masarikova 25, 21000 Novi Sad, Serbia

Tel: +381649942022

goran.glamocic@pzsport.rs

E-mail: goran.glamocic@pzsport.rs 